\section{The State of World Fisheries and Aquaculture 2014}

Fisheries and aquaculture play a vital role in achieving FAO's Strategic Objectives of eliminating hunger, food insecurity and malnutrition. As reported in this edition of The State of World Fisheries and Aquaculture, people have never consumed so much fish or depended so greatly on the sector for their well-being as today. As the demand for fish increases, the sector is also striving to be more productive and sustainable and to enable more inclusive and efficient systems while reducing rural poverty and enhancing the resilience of livelihoods to disasters, crises and climate change.

Global fish production growth continues to outpace world population growth. In 2012, while global marine capture fishery production was stable at about 80 million tonnes, global aquaculture production set another all-time high at more than $\mathbf{9 0}$ million tonnes (including almost 24 million tonnes of aquatic plants). Aquaculture remains one of the fastest-growing food-producing sectors and is set to play a key role in meeting the rising demand for fishery products.

The proportion of assessed marine fish stocks fished within biologically sustainable levels exceeded 70 percent in 2011, while fewer than 30 percent of fish stocks were overfished. Of the stocks assessed, fully fished stocks accounted for over 60 percent and underfished stocks about 10 percent.

The share of fisheries production used for direct human consumption increased from about 70 percent in the 1980s to more than 85 percent (136 million tonnes) in 2012.

With this increasing production and greater availability for consumers, per capita fish consumption continues to rise - up from $10 \mathrm{~kg}$ in the 1960 s to more than $19 \mathrm{~kg}$ in 2012 - driven by higher demand from a growing population, rising incomes, and more efficient distribution channels.

Fish remains an ever-important source of energy, protein and a range of essential nutrients, accounting for almost 17 percent of the global population's intake of animal protein. Moreover, fish provided nearly 3 billion people with

\section{KEY MESSAGES}

- World aquaculture production continues to grow and now provides almost half of all fish for human consumption.

- Fisheries and aquaculture supports the livelihoods of 10-12 percent of the world's population, and provides a wide range of economic opportunities.

- As a concentrated source of protein, essential fatty acids and micronutrients, fish is important for diversified and healthy diets.

- Small-scale fisheries are gaining more global recognition as being integral to growth but also highly vulnerable to impacts linked to issues ranging from climate change to tenure disputes.

- Reducing wastage - especially post-harvest losses in small-scale fisheries will make more fish available for food and boost use of by-products.

- The Code of Conduct for Responsible Fisheries, nearly 20 years on, serves as an internationally accepted benchmark and framework for the sustainable use of aquatic resources.

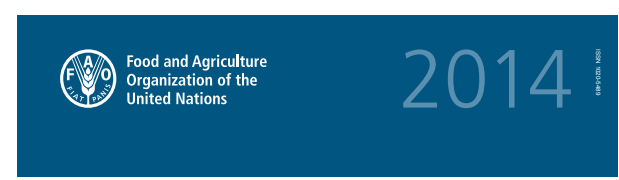

The State of World

Fisheries and Aquaculture

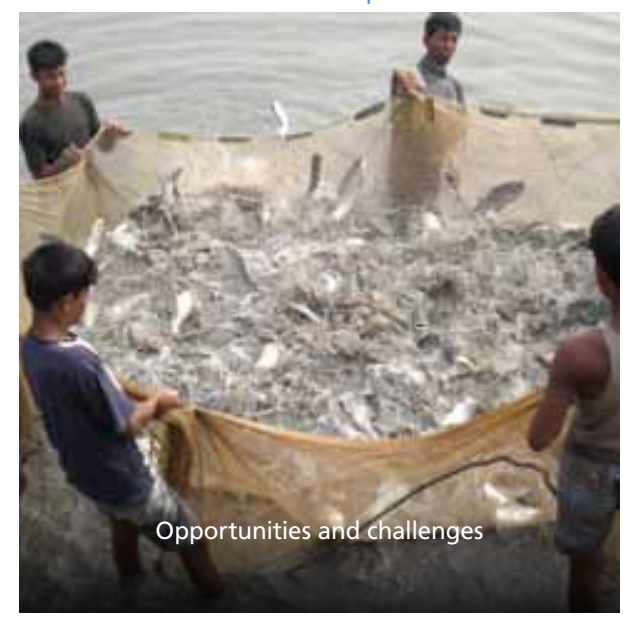

June 2014

ISBN: 978-92-5-108275-1

ISSN: 1020-5489

$223 \mathrm{pp}$.

$210 \times 297 \mathrm{~mm}$

Also available in:

Arabic, Chinese, French, Russian, Spanish

Subject categories:

Fisheries, aquaculture, food security,

food wastage, nutrition

The State of World Fisheries and Aquaculture, the flagship publication of the FAO Fisheries and Aquaculture Department, presents a global review of fisheries and aquaculture including trends and statistics. It highlights issues debated worldwide and profiles future scenarios to provide readers with the most current global view and perspectives on fisheries and aquaculture. 
Relative contribution of aquaculture and capture fisheries to food fish consumption

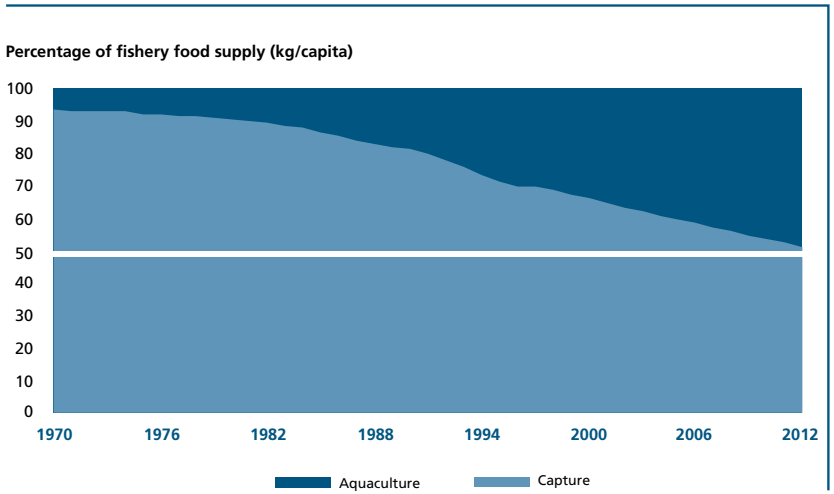

almost 20 percent of their intake of animal protein, and 4.3 billion people with about 15 percent of such protein. Protein from fish is a crucial nutritional component in some densely populated countries where total protein intake levels may be low. Consuming fish is particularly important during pregnancy and the first two years of life and can help lower the risk of coronary heart disease mortality.

The fisheries and aquaculture sector is also a source of employment and income, supporting the livelihoods of 10-12 percent of the world's population.

In 2012, employment in the sector grew faster than the world's population, with almost 60 million people engaged in the primary sector, 90 percent small-scale fishers and 15 percent of them women. In post-harvest activities such as processing, women can account for up to 90 percent of workers.

Fish remains among the most traded food commodities worldwide, worth almost US\$130 billion in 2012 and pointing to an increase for 2013. The aggregate FAO Fish Price Index reached a record high in October 2013. Trade in fish and fishery products is especially important for developing nations, in some cases worth over half of the total value of traded commodities. Developing economies saw their share rise to 54 percent of total fishery exports by value in 2012, and more than 60 percent by quantity (live weight).

Almost 20 years since its adoption, the Code of Conduct for Responsible Fisheries remains a benchmark for achieving sustainable fisheries and aquaculture. Globally, the priority for implementation of the Code is the establishment of responsible fisheries with due consideration of relevant biological, technical, economic, social, environmental and commercial aspects.

Within the broad ambit of governance, FAO is promoting "Blue Growth" as a coherent framework for the sustainable, integrated and socio-economically sensitive management of oceans and wetlands, focusing on capture fisheries, aquaculture, ecosystem services, trade and social protection of coastal communities.
World fish utilization and supply

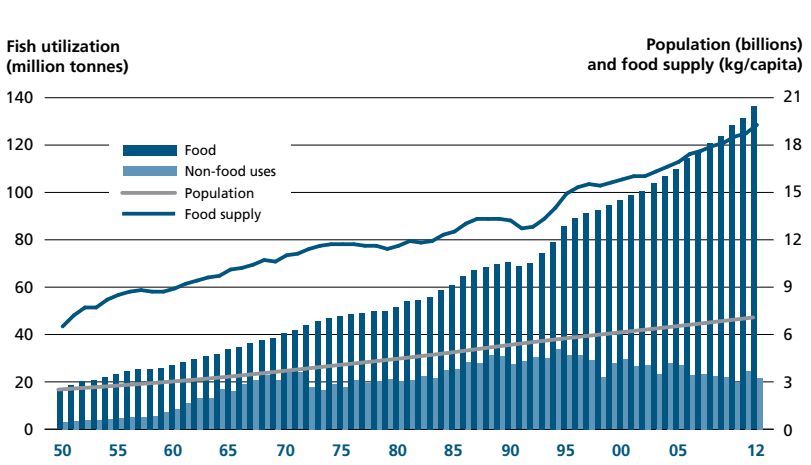

In addition, FAO is coordinating the "Global sustainable fisheries management and biodiversity conservation in the Areas Beyond National Jurisdiction Program", known as Common Oceans, to promote efficient and sustainable management of fisheries and biodiversity conservation.

At the same time, at global level, the contributions of smallscale fisheries to poverty alleviation and food and nutrition security are being increasingly recognized, most notably in the Rio+20 outcome document (The Future We Want), in the Voluntary Guidelines for the Responsible Governance of Tenure of Land, Fisheries and Forests in the Context of National Food Security, and in the development of the Voluntary Guidelines for Securing Sustainable Small-scale Fisheries in the Context of Food Security and Poverty Eradication.

Illegal, unreported and unregulated (IUU) fishing remains a major threat to marine ecosystems, with many States striving to implement the International Plan of Action to Prevent, Deter and Eliminate Illegal, Unreported and Unregulated Fishing.

Other themes highlighted in The State of World Fisheries and Aquaculture 2014 include: the role of aquaculture in improving nutrition; the importance of reducing post-harvest losses in smallscale fisheries; and challenges and opportunities for utilization of fisheries by-products. The Outlook section emphasizes approaches for meeting future fish demand, underlining aquaculture's increasingly important role.
Food and Agriculture Organization of the United Nations Viale delle Terme di Caracalla

00153 Rome, Italy

Tel.: +390657051 